\title{
THE IMPACT OF POND ON WATER QUALITY IN THE ČERMNÁ STREAM
}

\author{
Věra Hubačíková', Petra Oppeltová1 \\ 1 Department of Applied and Landscape Ecology, Faculty of AgriSciences, Mendel University in Brno, \\ Zemědělská 1, 61300 Brno, Czech Republic, e-mail: verah@mendelu.cz
}

Received: 2016.10 .25

Accepted: 2016.11.16

Published: 2017.01.01

\begin{abstract}
The aim of this study is to demonstrate the positive impact of ponds on water quality in a small stream Čermná. Four sites were sampled regularly every month for one year. Simultaneously, $\mathrm{pH}$ and temperature were measured continuously. The concentration of ammonia nitrogen, nitrate nitrogen and nitrite nitrogen were determined by subsequent analysis of the water samples. The results were classified in compliance with Government Decree (GD) No. 401/2015 Coll., as amended, and Czech standard ČSN 75 7221. High concentrations of ammonia nitrogen that were detected during the whole period are the result of the discharge of all wastewater from the village of Dolní Čermná to flow Čermná. Although the results showed a positive effect pond Čermenský, during the growing season the concentration of ammonia nitrogen at SP No. 2 placed under the pond increased mainly due to fertilizing pond by manure to increase nutrients for the fish population in the pond.
\end{abstract}

Keywords: ammonia nitrogen, nitrate nitrogen, nitrite nitrogen, concentration, waste water

\section{INTRODUCTION}

Ponds form an important and integral part of our landscape. They naturally integrate the impacts of human activities in their watersheds. Great potential in the retention of nutrients, especially from printed, diffusion and small point sources is naturally hidden in ponds. [Potužák, Duras, 2014] Ponds have several important functions, not only retention one, but even to transform the quality of water, which flows throw the pond, it is mainly the ability of nutrients retention. [Potužák, Duras, 2012]. Nitrates are oppositely considered a unequivocally harmful substance, deteriorating water quality. We are afraid of devaluation of drinking water sources and eutrophication of the seas - wrongly - also eutrophication of our surface waters. During the campaign against nitrates we forgot that in our - mostly eutrophicated - waters, nitrates have a very important function. They are the redox buffer [Duras, 2006].

Fertilizing and feeding ponds is an important source of nutrients. Large amounts of organic matter accumulate at the bottom of ponds over years. Complete feed, which is used in intensive farming of fish, is degraded to a large amount of organic waste. Regular feeding and fertilization in ponds causes accumulation of organic matter, nitrogen and phosphorus in the sediment. [MIZANUR et al., 2004]. Draining the pond is considered a critical period as a source of nutrients for downstream river below ponds. [BANAS et al., 2002]. Similar problems of water quality of surface waters is also solved by Húska et al. [2014].

Dolní Čermná village is located in the foothills of Orlice Mountains, in Pardubice - Lanškroun region. Its cadastral is in the altitude from 398 to $528 \mathrm{~m}$ above the sea level. The village stretches in the length $3 \mathrm{~km}$ in the valley of Čermná stream, which flows into the Tichá Orlice under the hill Hůra (519 $\mathrm{m}$ above sealevel). Čermná stream catchment area is $28157 \mathrm{~km}^{2}$, the length of the flow is $12580 \mathrm{~km}$. The number of hydrological order is from $1-02-02-022$. Povodí Labe, s.p., is the watercourse administrator. The brook Čermná raises above the Horní Čermná in section Zlomy, flows west, then north and then becomes a left tributary of the Tichá Orlice in its 
$71.2 \mathrm{~km}$. Čermná opens into the river Tichá Orlice. Čermná has several little tributaries, there are most important: from the right Háj stream (in 6498 km) and Bobravka stream, which flows from the left through so called gamekeepers' pond and flows into Čermenský pond. The area of Čermenský pond is about 16 hectares and "the hunting" pond of approximately 0.7 hectares. Extensive revitalization of the Čermenský pond began in 2005 and was completed in early 2007 . Water surface before revitalization was 11 hectares and $140000 \mathrm{~m}^{3}$ of pond sediment were taken. The Čermenský pond is semi-intensive used for fish farming with regular haul. According to Hartman and Regendy [2016] a semi-intensive fish farming in ponds that breeding, which is provided by natural production, feeding and supplying nutrients while respecting their balance invested (fertilizers and feed) and depleted addition sport fishing. Optimization of ratio and content of nutrients is done by fertilization in order to increase natural production of ponds.

According Schäperclause a Mathiase von Lukowicze [1998] stable solid organic fertilizers have up to $90 \%$ of organically bound nitrogen, it belongs to the so-called "hard bottom" (it can be stocked for vegetation), acts as a carbon fertilizer, input of nitrogen and phosphorus is insignificant, doses of $0.5-5 \mathrm{t} \cdot \mathrm{ha}^{-1}$.

In the area of interest the Čermná stream has mainly natural channel, only some sections in urban areas and some of its tributaries are adjusted. Treatment capacity amounts to about $\mathrm{Q}_{2}-\mathrm{Q}_{5}$. In the catchment of Čermná stream there are water sources for Lanškroun aqueduct that supplies to the city Lanškroun and adjacent villages (Albrechtice, Sázava, Žichlínek Horní and Dolní Třešňovec, Lubník) and Horní and Dolní Čermná by drinkable water. Protection of groundwater in the area of interest is secured by Act no. 254/2001 Coll. on waters and amending some laws (the Water Act), as amended. Water resources have established a protection zone with 2nd degree - Zone 1 and Zone 2. PZ 2 degrees encroaching on the cadastral of Horní Čermná, Dolní Čermná and Bystřec with a total area of $8.73 \mathrm{~km}^{2}$. The largest forest complexes in Dolní Čermná - Horní Dobranka consist mainly of spruce and mixed forests. Forest coverage area is $30.3 \%$. The other area of the country is made up of agricultural land, which is intensively managed. The area of interest is not classified in vulnerable areas according to Decree no. 262/2012 Coll., as amended. Community has united sewerage with local outcome of the sections directly to a recipient. The rest of the objects have deceived sewage water in poorly drained into septic tanks or individual form with the outlet (e.g. infiltration). Sewage water from sinks is uncontrolled exported to agricultural land. There is no industry source of sewage in the area. The cadastral of Dolní Čermná belongs to the moderately warm and humid climate region, with the average temperature $6-7{ }^{\circ} \mathrm{C}$ and precipitation $650-750 \mathrm{~mm}$.

\section{MATERIALS AND METHODS}

The length of monitored stretch is about 3.640 $\mathrm{km}$. Water in this stretch was regularly monthly intervals for 1 year sampled from four sites SP No. 1, SP No. 2, SP No.3, SP No. 4. Sampling profile 1 is located at the $300 \mathrm{~m}$ above the pond, profile No. 2 is about $15 \mathrm{~m}$ below the pond, profile No. 3 is situated in the village built and profile No. 4 profile 4 is located in the end municipality Dolní Čermná (Figure 1).

At each sampling profile, the $\mathrm{pH}$ and temperature were determined in the field using the portable multimeter HQ30d and particular INTELLICAL probes from the HACH LANGE Company, fabricated in USA.

Each sample was taken as a one-time sample and put directly into a polyethylene container rinsed at least once with a sample of water. The samples were placed in the fridge and processed within 24 hours.

There are several indicators which were monthly determined: nitrate nitrogen, nitrite nitrogen, ammonia nitrogen. On the sites $\mathrm{pH}$ and temperature of water were measured.

Samples were processed in the Water Management Laboratory of the Department of Applied and Landscape Ecology of Mendel University in Brno. The analyses were performed by spectrophotometer DR/4000 from HACH LANGE Company, fabricated in USA. For determination of chosen indicators (nitrate nitrogen, ammonia nitrogen and nitrite nitrogen) the samples are filtered and subsequently treated according to manual of HACH LANGE Company. Laboratory work mainly consisted of the precise uptake (the blank sample and the sample) and subsequent adding of reagents, then mixing, keeping of given time intervals and inserting both samples into the spectrophotometer according to Hach Lange company method. 


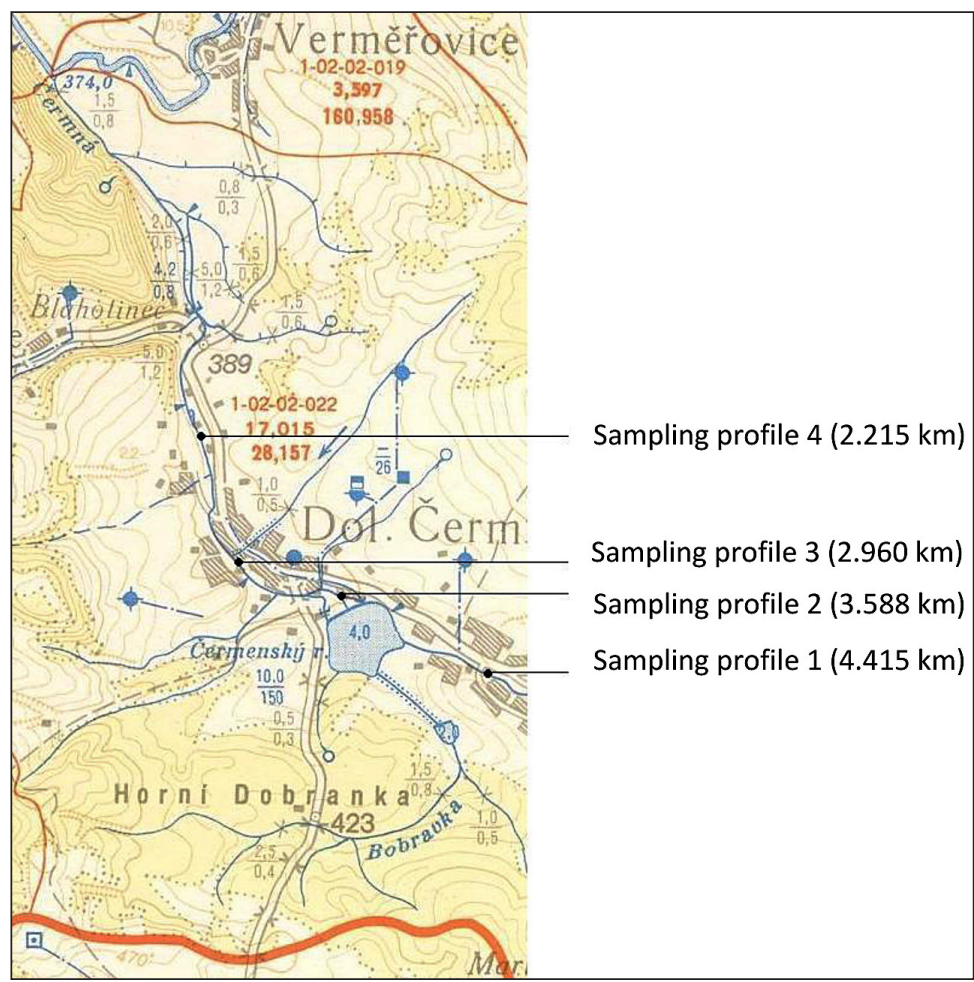

Figure 1. Sampling profiles on the Dolní Čermná [www.heis.cz, Hubačíková 2016]

The results obtained were evaluated in compliance with Government Decree No. 401/2015 Coll., as amended (Table 1).

\section{RESULTS}

The resulting concentrations of substances under research manifest considerable instability during the year, which can most likely be attributed to large changes in flow rates in different seasons.

The $\mathrm{pH}$ value has in the direction downstream fluctuating trend (Figure 2). Government Decree No. 401/2015 Coll., as amended, stipulates an average $\mathrm{pH}$ from 6 to 9 . The $\mathrm{pH}$ average value did not exceed this environmental quality standard at any of the profiles observed.

Government Decree No. 401/2015 Coll., as amended specifies the Environmental Quality Stan-

Table 1. Limit values of chosen indicators according to GD No. 401/2015 Coll

\begin{tabular}{|l|c|c|}
\hline \multirow{2}{*}{ Indicator } & \multirow{2}{*}{ Units } & $\begin{array}{c}\text { Environmental quality standard } \\
\text { GD No. 401/2015 Coll. }\end{array}$ \\
\cline { 3 - 3 } & & Average value \\
\hline Nitrite nitrogen & $\mathrm{mg} \cdot \mathrm{l}^{-1}$ & $0.08-0.12$ \\
\hline Nitrate nitrogen & $\mathrm{mg} \cdot \mathrm{l}^{-1}$ & 5.4 \\
\hline Ammonia nitrogen & $\mathrm{mg} \cdot \mathrm{l}^{-1}$ & 0.23 \\
\hline $\mathrm{pH}$ & - & $5-9$ \\
\hline
\end{tabular}

dard (EQS) form ammonia nitrogen $0.23 \mathrm{mg} \cdot \mathrm{l}^{-1}$ (Figure 3). All measured values for the determination of ammonia was higher than the EQS (the lowest concentration was measured in October in the SP value No. $20.282 \mathrm{mg} \cdot \mathrm{l}^{-1} \mathrm{~N}-\mathrm{NH}_{4}^{+}$). Elevated levels of ammonia nitrogen indicate the presence of sewage and fecal contamination. Ammonia nitrogen concentrations are fluctuating throughout the year in relation to the production of waste water, pond fertilization and subsequent dilution in the recipient. A large portion of waste water from households leads to a recipient in the village of Dolní Čermná and thus leads to a considerable pollution of the stream. At the same time Čermenský pond is in the growing season organic fertilized by manure, which is also reflected on the increased concentration of ammonia nitrogen in SP No. 2, sometimes there occurs on the SP No. 2 to lower concentrations. Other tributaries of sewage from the village increased concentration on other monitored profiles.

EQS for nitrite nitrogen is not set by Government Decree No. 401/2015 Coll., as amended, but the regulation establishes requirements for the use of water, a limit for salmon is $0.09 \mathrm{mg} \cdot 1^{-1} \mathrm{~N}-\mathrm{NO}_{2}{ }^{-}$ and for carp fish $0.14 \mathrm{mg} \cdot \mathrm{l}^{-1} \mathrm{~N}^{-\mathrm{NO}_{2}-}$ (Figure 4). The highest value of $\mathrm{N}^{-\mathrm{NO}_{2}}{ }^{-}$was recorded in July in SP No. 1 when the concentration of $\mathrm{N}^{-\mathrm{NO}_{2}}{ }_{2}^{-}$ reached $0.087 \mathrm{mg} \cdot l^{-1}$, which would correspond to the values of breeding salmon fish in terms of ni- 


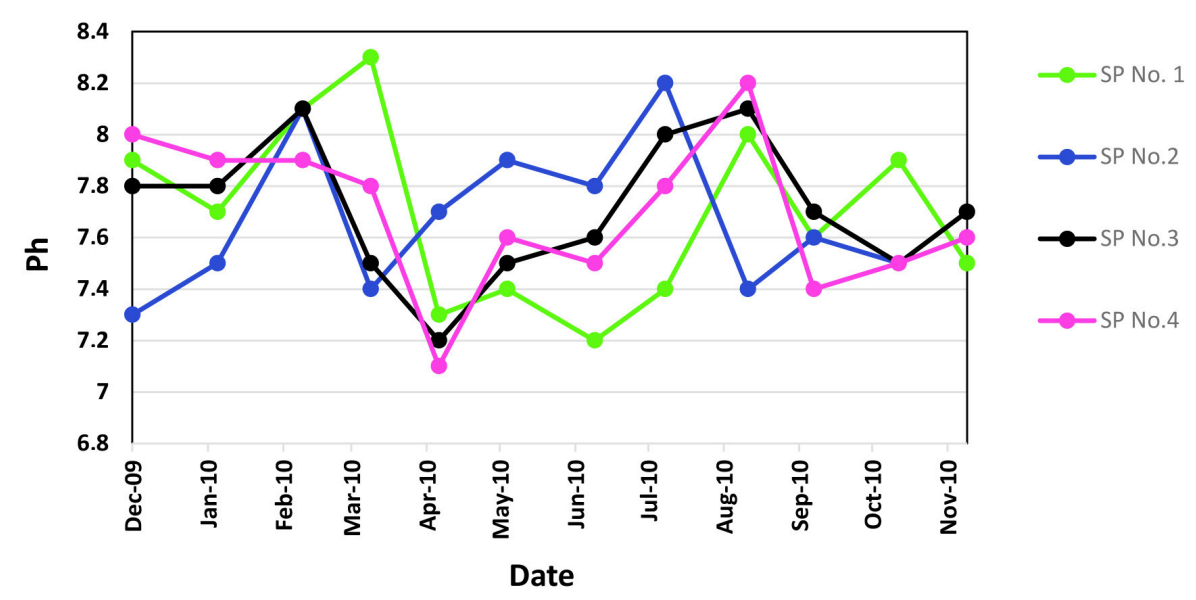

Figure 2. The development of $\mathrm{pH}$

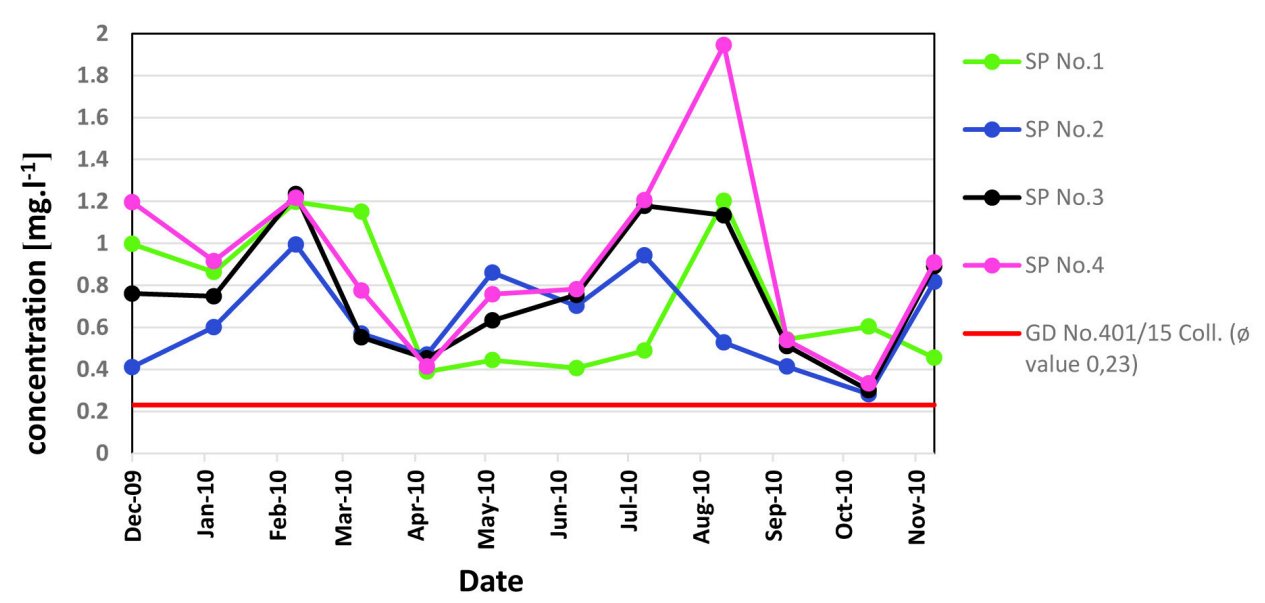

Figure 3. The development of ammonia nitrogen concentrations

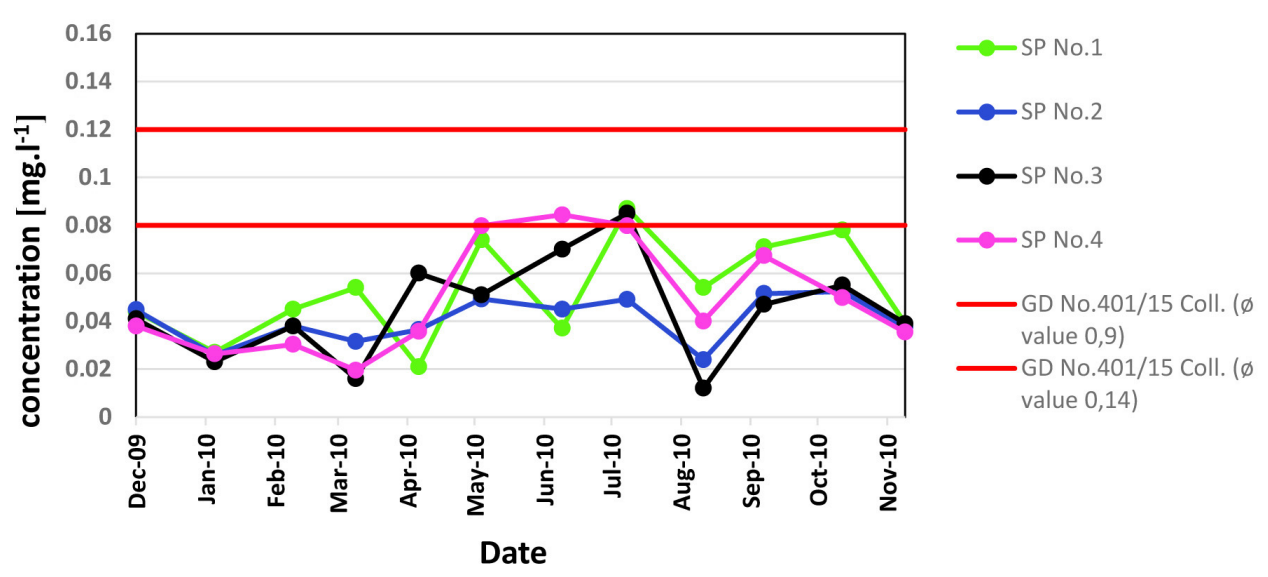

Figure 4. The development of nitrite nitrogen concentrations

trite nitrogen. As Pitter states [2009] nitrites usually occur in the low concentrations because of their chemical and biochemical instability, which is changing rapidly in a short time, hence typical concentrations for different types of water can be hardly showed. Nitrate nitrogen is in the area of interest throughout the year occurs below the limit of EQS (5.4 mg $\left.\cdot 1^{-1} \mathrm{~N}^{-\mathrm{NO}_{3}}{ }^{-}\right)$. The graph (Figure 5) shows that the highest readings were on SP No. 1 (except December where SP 1 is the lowest of all SP) and below the pond (SP No. 2), the value was nearly always lower than in the SP No. 1, which shows that at that time the pond captured nitric nitrogen. It is evident that the lowest values during the year were in the summer. Heteša, Kočová [1997] states that in the summer the nitrate con- 


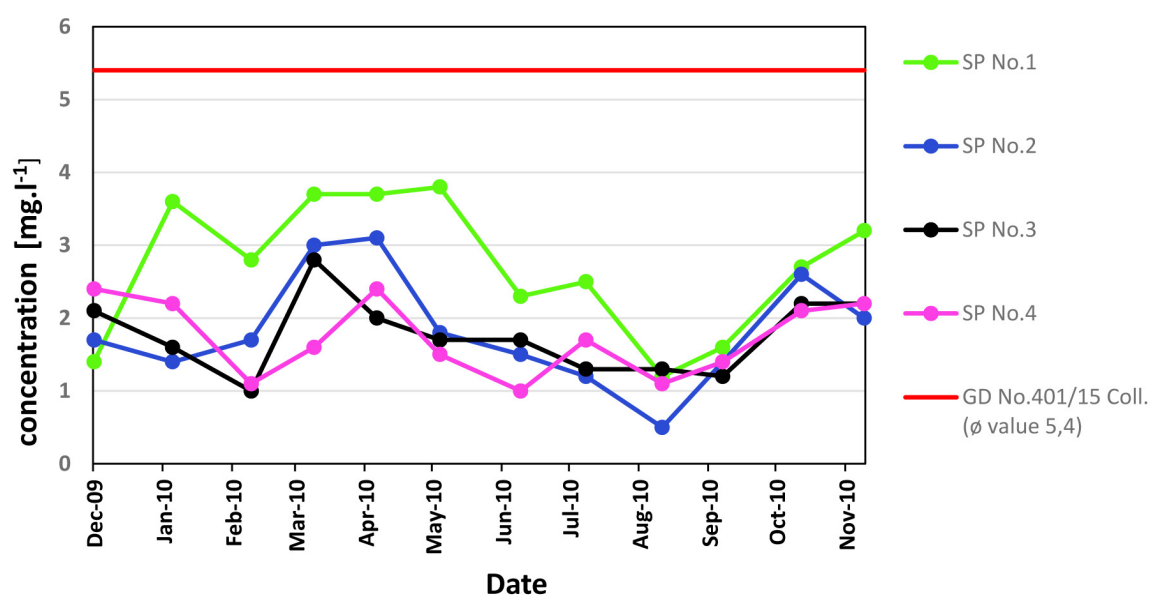

Figure 5. The development of nitrate nitrogen concentrations

tent quickly decreases and increases in the winter, which is related to the consumption of plants during the summer and its regeneration of organic substances in the winter.

\section{DISCUSSION}

In the overall assessment of the development of selected indicators in time we can observe positive results in accordance with regulations in the Czech Republic. Only Ammonia nitrogen exceeds the limits during the entire period.

An application of solid organic fertilizers into the pond increases the concentration of ammonia pollution (Figure 3). Schäperclaus and Lukowicz [1998] reported that the solid organic fertilizer (manure) are applied partially before the vegetation $(60 \%$ of annual dose) typically within piles and more than $40 \%$ in the first third of the growing season across the board on the water.

The Ammonia nitrogen is the primary product of the decomposition of most organic nitrogenous substances animal and vegetable origin. Sewage water is primarily anthropogenic source of ammonia nitrogen organic origin. Nitrogen fertilizers are a major anthropogenic source of organic origin ammonia nitrogen. Sewage is rich in ammonia, the concentration range in the tens of $\mathrm{mg} \cdot \mathrm{l}^{-1}$. Faeces (urine) and degradation products of nitrogenous organic substances are the main source. The content is highly variable, because different biological transformations of nitrogen compounds have been going in sewers. Ammonia nitrogen are toxic to fish; its toxicity depends largely on the $\mathrm{pH}$ value. [Pitter, 2009] Dissociated form of $\mathrm{N}_{-} \mathrm{NH}_{4}^{+}$predominates at lower $\mathrm{pH}$ to 8 , in base there occurs only $\mathrm{N}^{-\mathrm{NH}_{3}^{-}}$.
Nitrates arise mainly secondary to the nitrification of ammonium nitrogen and they are final degree of decomposition of nitrogenous organic compounds in the oxygenated environment. In natural waters, nitrate concentration was also changing depending on the growing season. Nitrates are among the important nutrients that adversely affect the eutrophication of surface waters [Pitter, 2009].

\section{CONCLUSIONS}

The paper focuses on monitoring of Čermenský pond and its impact on water quality in Čermná stream that flows through the village Dolní Čermná. The length of the reference flow was $3640 \mathrm{~km}$. Čermná stream catchment area is $28157 \mathrm{~km}^{2}$, the total length of the flow is $12580 \mathrm{~km}$. Sewage water from the municipality is drained into the stream because there is no is not a wastewater treatment plant. There is Čermenský pond on the stream. After restoration in 2005 the pond has an area of about 16 hectares and it is semi intensive used for fishing purposes. Water quality monitoring in the flow were determined in 4 sites where regular sampling took place throughout the year. The following quality indicators were evaluated: in the field $\mathrm{pH}$, temperature; in the laboratory - nitrate nitrogen, ammonia nitrogen and nitrite nitrogen. Samples were processed in the Water Management Laboratory of the Department of Applied and Landscape Ecology of Mendel University in Brno. The analyses were performed using spectrophotometer DR/4000 from the $\mathrm{HACH}$ Company. The results obtained were evaluated in compliance with the Czech standard ČSN 75 
7221 and Government Decree No. 401/2015 Coll as amended.

The results show that the combination of sewage and use of manure as a fertilizer to increase the nutrients in the pond has a very negative effect on the results of monitored indicators of water quality (ammonia nitrogen, nitrate and nitrite nitrogen). The values of ammonia nitrogen detected at all points throughout the year are nearly alarming (against the EQS $0.23 \mathrm{mg} \cdot \cdot^{-1}$ ). In the future, it is therefore necessary to establish public sewer and distract all waste water from this village sewage to the wastewater treatment plant and to continue to prevent the pollution of the watercourse Čermná by sewage water. It is also necessary to avoid the application of sewage water from septic tanks and household of the surrounding land. All that is needed both to improve water quality in the watercourse Dolní Čermná, and to maintain the quality of groundwater resources on the cadastral municipality.

After the construction of a wastewater treatment plant in the village would be appropriate to continue to monitor the flow of whether the indicators monitored and water quality in the stream Čermná improve on the basis of these measures. In the course of monitoring would be appropriate to focus on breeding the fish in the pond.

\section{RERERENCES}

1. Banas D., Masson G., Leglize L., Pihan J., 2002. Discharge of sediment, notrogen $(\mathrm{N})$ and phoshorus $(\mathrm{P})$ during the emptying of extensive fishponds: effect of rain-fall and management practices. Hydrobiologia, 472 (1-3), 29-38.

2. Duras J., 2006. Úloha dusičnanů v nádržích a jejich povodí - vliv na koloběh fosforu, Pitná voda 2006, W@ET Team, České Budějovice, pp. 424.

3. Hartman P., Regenda J., 2016. Praktika v rybníkářství, Vodňany: Jihočeská univerzita v Českých Budějovicích, pp. 375.

4. Húska D. et al., 2014. Vplyv antropogénných činitel'ov na kvalitu povrchových vod v čiastkovom povodí toku Žitava, 1. vyd. Nitra: Slovenská pol'nohospodárska univerzita, pp. 181.

5. Mizanur R., Yakupitiyage A., Ranamukhaarachchi S.L., 2004. Agricultural Use of Fishpond sediment for Environmental Amelioration. Thamnasat International Journal of Sience and Technology, 9(4), 12.

6. Potužák J., Duras J., 2014. Jakou roli mohou hrát rybníky v zemědělské krajině?, Vodárenská biologie 2014, Praha, Česká Republika, pp. 230.

7. Potužák J., Duras J., 2012. Jsou rybníky během povodní našimi spojenci nebo časovanou bombou? Vodárenská biologie 2012, Praha, Česká Republika, pp. 218.

8. Pitter P., 2009. Hydrochemie, 4. Akt. Vyd. Praha: VŠCHT Praha, pp. 592.

9. Schäperclaus W., Lukowicz M., 1998. Lehrbuch der Teichwirtschaft, 4., neubearbeitete Auflage, Parey Buchverlag Berlin 1998, pp. 590.

10. Hydroekologický informační system VÚV TGM. In: heisvuv.cz. [online: 2016.09.24]. Available from: www. http://www.heisvuv.cz/data/webmap/isapi.dll? $m a p=m p \_h e i s \_v o d a \& t m p l=a j a x$ main \& iframe $=1 \&$ legend_hide $=0 \&$ query selection $=1 \&$ fulltext_checked $=1$ 